Ks. Jerzy Chmiel

\title{
Z DZIALALNOŚCI POLSKIEGO TOWARZYSTWA TEOLOGICZNEGO W KRAKOWIE W R. 1986
}

\author{
I. STAN TOWARZYSTWA
}

1.1. Walne Zebranie odbyło się dnia 22 I 1986 r. o godz. 16.15 w auli Wyższego Seminarium Duchownego w Krakowie przy ul. Podzamcze 8.

1.2. Zarząd został wybrany na Walnym Zebraniu w następującym składzie: prezes - ks. doc. dr hab. Jerzy Chmiel

wiceprezes - o. dr Jan Wichrowicz, OP

sekretarz - ks. lic. Antoni Okrzesik

skarbnik - ks. Zbigniew Gerle

bibliotekarz - ks. lic. Jan Bednarczyk

1.3. Komisja Kontrolująca została wybrana w składzie

1.3. Komisja Kontrolująca została wybrana w składzie:

przewodniczący - ks. dr Kazimierz Waliczek

członkowie - ks. dr hab. Jan Dyduch

ks. dr Stefan Ryłko, CRL

1.4. Sąd Koleżeński - wybrano w składzie:

przewodniczący - ks. dr hab. Adam Kubiś

członkowie - ks. dr Stefan Cichy

ks. dr Stanisław Bizuń

1.5. Zebrania Zarządu. W okresie sprawozdawczym Zarząd odbył trzy zebrania: 26 II 1986; 10 X 1986; 12 XII 1986.

1.6. Członkowie. Stan członków Towarzystwa na dzień 31 XII 1986

wynosił: członków zwyczajnych -266

wspierających -32

W roku sprawozdawczym przyjęto 10 nowych czlonków zwyczajnych:

ks. dr Stefan Dobrzanowski

ks. dr Jan Chrapek, CSMA

ks. dr Edward Formicki CM

o. dr Korneliusz Jackiewicz, OCist

o. dr Oktawian Roman Jusiak, OFMBern

o. dr Niward Karsznia, OCist

o. dr Paweł Mynarz, OCist

ks. dr Wladysław Majkowski, SCJ

o. mgr Tytus Kondys, OFMRef

ks. dr Józef Makselon

oraz 1 czlonka wspierającego: dr med. Jacek Danowski

1.7. Honorowe medale Towarzystwa otrzymali:

ks. prof. dr hab. Aleksander Usowicz, CM

ks. prof. dr hab. Bolesław Kumor

prof. dr hab. Janina Bieniarzówna

prof. dr hab. Wojciech Maria Bartel

1.8. Zmarli członkowie:

ks. dr Andrzej Bober, SI

mgr inż. Jan Stec

Requiescant in pace! 


\section{DZIAŁALNOŚĆ ODCZYTOWA TOWARZYSTWA}

Towarzystwo prowadziło działalność odczytową w następujących sekcjach:

2.1. Sekcja filozoficzna. Kierownik: ks. doc. dr hab. Henryk Piszkalski, CSsR. Trzy zebrania z trzema referatami:

- 21 X 1986 - ks. doc. dr hab. Henryk Piszkalski: „Aspekty psychologiczne współczesnej inżynierii genetycznej"

- 18 XI 1986 - ks. doc. dr hab. Krzysztof Szczygieł: „Biochemiczne podstawy inżynierii genetycznej"

- 16 XII 1986 - ks. prof. dr hab. Tadeusz Wojciechowski: „Z problematyki cudów"

2.2. Sekcja biblijno-liturgiczna. Kierownik: ks. doc. dr hab. Tomasz Jelonek. Odbyły się 4 sesje z 10 referatami:

- 18 II 1986 - ks. dr hab. Stanisław Pisarek: „Teologia Jezusa”

- o. lic. Augustyn Chadam, OFMBern: „Kto jest winien śmierci Jezusa?”

- 21 II 1986 - sesja Studium Syndologicznego pt. „Wykorzystanie badań Całunu Turyńskiego w rozwoju kultu Męki Pańskiej i Eucharystii"

- dr Stanisław Waliszewski: „Bezpośrednia przyczyna śmierci Chrystusa na krzyżu w aspekcie historycznym"

- doc. dr hab. Władysław Fenrych: „O metodach badania Całunu Turyńskiego"

- mgr inż. Jerzy Dołęga-Chodasiewicz: „O możliwościach popularyzacji Calunu"

- ks. doc. dr hab. Jerzy Chmiel: „Aspekty teologiczne Całunu w związku z kultem Męki Pańskiej i Eucharystii"

- 2 VI 1986 - ks. dr Tadeusz Brzegowy: „, Ku dosłownej interpretacji Pieśni nad pieśniami"

- ks. doc. dr hab. Tomasz Jelonek - „Uwagi na temat religioznawstwa w szkołach średnich"

- 19 XI 1986 - ks. dr Antoni Paciorek: „Eucharystia jako synteza czasu zbawienia według J 6"

- o. dr Damian Szojda OFM: „Indywidualny moment Eucharystii na tle uczty paschalnej i uczty wieczernikowej".

2.3. Sekcja apologetyczno-religioznawcza. Kierownik ks. doc. dr hab. Adam Kubiś. Odbyło się 1 zebranie z 1 odczytem:

- 26 V 1986 - ks. prof. dr hab. Eugeniusz Florkowski: „Chrześcijaństwo a wcześniejsze systemy religijne"

2.4. Sekcja dog maty c z n o-mora ln a. Kierownik o. dr Jan Wichrowicz, OP. Odbyło się 6 zebrań z 6 referatami:

- 13 I 1986 - o. dr Otto Filek, OCD: „Wartości przedmiotowo-badawcze „Dziennika” Sł. B. Anieli Salawy (1881-1922) dla rozwoju teologii mistycznej w Polsce"

- 10 II 1986 - ks. dr Engelbert Gorywoda, SDB: „Nowa interpretacja teologiczna dogmatu teistycznego"

- 3 III 1986 - o. lic. Wojciech Giertych, OP: .,Tomizm po Freudzie. Przydatność tomistycznej koncepcji uczuć w leczeniu nerwic według A. A. Terruwe i C. W. Baarsa"

- 6 X 1986 - ks. prof. dr hab. Jan Sieg, SI: „Refleksje nad teologia wyzwolenia w świetle Instrukcji Kongregacji Nauki Wiary o chrześcijańskiej wolności i wyzwoleniu"

- 3 XI 1986 - ks. dr Tadeusz Biesaga, SDB: „Egzystencjalna propozycja wyzwolenia człowieka"

- 1 XII 1986 - o. dr Wiesław Szymona, OP: „Współczesny stan badań nad ortodoksją Mistrza Eckharta" 
2.5. Sekcja historyczna. Kierownik o. doc. dr hab. Marian Kanior, OSB. Odbyły się 4 zebrania i 1 sesja wespół $\mathrm{z}$ Wydz. Hist. Kościoła PAT w Krakowie:

- 15 I 1986 - o. dr hab. Marian Kanior, OSB: „Polska Kongregacja Benedyktyńska św. Krzyża"

- 26 I I1986 - ks. doc. dr hab. Jerzy Wolny: „Misja Lucyny Frassati Gawrońskiej i abp Adam Stefan Sapieha w czasie II wojny światowej"

- 19 III 1986 - o. dr Bolesław Micewski: „Bogdan Jański, geneza Księży Zmartwychwstańców"

- 23 IV 1986 - ks. prof. dr hab. Bolesław Kumor: „Podstawy historyczne kultu Matki Bożej w Polsce"

- 12 XI 1986 - sesja naukowa nt. „Chrzest Litwy i jego kościelno-polityczne następstwa”. Wygłoszono następujące referaty:

- ks. doc. dr hab. Jerzy Wolny: Wprowadzenie

- dr Stanisław Szczur (UJ): „Dyplomatyczne przygotowania do unii krewskiej"

- dr Tadeusz Trajdos: „Unia Jagiełły”

- o. prof. dr Paulius Rabikauskas, SI (Rzym): "Chrzest Litwy”

- ks. prof. dr hab. Bolesław Kumor: „Organizacja diecezji litewskich do końca XV w."

- ks. dr Tadeusz Krahel (ATK): „Wyższe duchowieństwo litewskie w XV w."

2.6. Sekcja kanonistyczna. Kierownik ks. prof. dr hab. Tadeusz Pieronek. Sekcja w okresie sprawozdawczym nie odbyła posiedzeń.

2.7. Sekcja misjologiczna. Kierownik ks. doc. dr hab. Antoni Baciński, CM. Odbyły się 2 posiedzenia z 2 referatami:

- 22 X 1986 - ks. doc. dr hab. Antoni Baciński, CM ,,Shuntehfu - misja polska Księży Misjonarzy św. Wincentego à Paulo i Sióstr Miłosierdzia w Chinach (1929-1949)"

- 26 XI 1986 - s. Franciszka Łoboda, OSU, „Z mojej pracy misyjnej w Indonezji"

2.8. Sekcja w Kalwarii Zebrzydowskiej. Kierownik sekcji o. dr Andrzej Pabin, OFM. Odbyły się 2 zebrania i 1 sesja:

- 14 II 1986 - ks. prof. dr hab. Stanisław Olejnik (ATK): „Spowiedzi specjalne w świetle najnowszych dokumentów Kościoła dotyczących Sakramentu Pojednania"

- 3 X 1986 - o. dr Feliks Marchewka, OFM: „Punkt wyjścia w dowodzeniu istnienia Boga u Dunsa Szkota”

- 26 XI 1986 - sympozjum naukowe nt. „Kult Matki Bożej Kalwaryjskiej w stulecie koronacji Obrazu (1887-1987)" wespół z Wydz. Historii Kościoła PAT w Krakowie:

- prof. dr hab. Hieronim Wyczawski, OFM (ATK): „O cudownych obrazach Matki Bożej w Polsce'

- ks. dr Stanisław Dobrzanowski: „Organizacja i stan duszpasterstwa w Diecezji Krakowskiej (XVII-XIX w.)"

- o. mgr Jan Grudziński, OFM: „Sanktuaria maryjne pod opieką Bernardynów (1800-1918)"

- o. lic. Augustyn Chadam, OFM: „Kult Matki Bożej w Sanktuarium Kalwaryjskim w XIX w."

- mgr Zuzanna Kazanowska: „Zasięg terytorialny kultu Matki Bożej Kalwaryjskiej w latach 1970-1980"

2.9. Sekcja w Tarnowie. Kierownik ks. dr Bolesław Margański. Odbyły się 3 zebrania z 3 referatami: 
- 13 V 1986 - ks. prof. dr hab. Leopold Regner: „Tarnowskie Seminarium Duchowne w latach trzydziestych"

- 18 XI 1986 - ks. prof. dr hab. Michał Heller: „Nauka a wiara próba zrozumienia dawnego konfliktu".

- 16 XII 1986 - ks. prof. dr hab. Jan Dudziak: „Struktura i rola „Kolegium Konsultorów" w diecezji według Kodeksu Prawa Kanonicznego"

2.10. Sekcja w Tuchowi e. Kierownik o. dr Stanisław Bafia, CSsR. Odbyły się 2 zebrania i 1 sympozjum:

- 28 II 1986 - o. dr W. Bołoz, CSsR: „Nowe feromy zadośćuczynienia w sakramencie pojednania"

- 25 IV 1986 - o. lic. R. Marcinek, CSsR: „Jubileusz 200-lecia diecezji tarnowskiej"

- $21 \times 1986$ - sesja z 7 referatami:

- prof. dr hab. Wl. Rostocki: „Sytuacja polityczno-spoleczna w Warszawie na przełomie XVIII i XIX w."

- ks. dr J. Wysocki; „Sytuacja religijno-moralna w Warszawie na przełomie XVIII i XIX w."

- o. dr A. Bazielich, CSsR: „Misje redemptorystów w okresie działalności św. Klemensa w Warszawie"

- o. dr G. Orlandi, CSsR (Rzym): „Gli anni 1748-1787 nella vita di San Clemente Hofbauer Suggerimenti per una rilettura"

- o. dr J. Heinzmann, CSsR (Szwajcaria): „Der homo apostolicus: Klemens Hofbauer"

- dr L. Grochowski: „Działalność oświatowa i opiekuńcza księży redemptorystów-benonitów w Warszawie w latach 1787-1808"

- prof. dr F. Ferrero, CSsR (Rzym): „Funcion historica de S. Clemente Hofbauer en la Congregacion del Smo Redemtor"

2.11. Sekcja w Katowicach. Kierownik ks. dr Stefan Cichy.

Odbyły się 4 zebrania $\mathrm{z} 4$ referatami:

- 24 IV 1986 - ks. doc. dr hab. Wincenty Myszor: „Chrześcijanie wobec zagadnień politycznych i społecznych w III i IV w."

- 18 V 1986 - bp dr Herbert Bednorz: „Niemiecki Katechizm dla dorosłych w świetle krytyki"

- 12 XI 1986 - ks. mgr Kazimierz Wolny: „Kult Miłosierdzia Bożego a Eucharystia"

- 1 XII 1986 - ks. mgr Kazimierz Wolny: „Religijno-społeczny aspekt kultu św. Barbary"

2.12. Sekcja socjologiczno-pastoralna powolana na mocy uchwały Zarządu Towarzystwa w dniu 10 X 1986 r. Kierownik ks. dr Stefan Dobrzanowski. Odbyła 1 posiedzenie informacyjno-organizacyjne w dniu 16 V 1986.

2.13. Podsumowanie statystyczne

$\begin{array}{ll}\text { zebrania sekcyjne } & -28 \\ \text { sesje i sympozja naukowe } & -7 \\ \text { ilość referatów i komunikatów } & -55\end{array}$

2.14. Uwagi: skontrum władz państwowych: Wydziału ds. Wyznań. Urzędu m. Krakowa odbyło się dnia 20 VI $1986 \mathrm{r}$. 
III. LIST UCZESTNIKOW WALNEGO ZEBRANIA

DO OJCA SWIETEGO JANA PAWEA II

Ojcze święty!

Waln Zebranie czlonków Polskiego Towarzystwa Teologicznego w Krakowie przesyła Waszej Swiątobliwości wyrazy najgłębszej czci, synowskiego oddania i chrześcijańskiej miłości.

Pragniemy w naszej działalności rozpowszechnić Twoją, Ojcze Swięty, naukę, zawartą w rozlicznych przemówieniach i dokumentach.

Prosząc Boga o obfite Łaski dla Waszej Swiątobliwości, szczególnie w tym nowym roku, zapewniamy o naszym trwaniu w apostolskiej jedności-komunii.

Kraków, 22 stycznia $1986 \mathrm{r}$.

Prezes, Zarząd i czlonkowie uczestnicy Walnego Zebrania (następują podpisy)

Kraków

KS. JERZY CHMIEL

\section{RE F L E K S JE I M A T E R I A L Y}

\section{Ks. Norbert Hoslinger}

\section{DROGI I ŚRODKI SLUŻĄCE PRZYBLIŻENIU BIBLII LUDZIOM}

Konstytucja dogmatyczna II Soboru Watykańskiego O Objawieniu Bożym stawiając wymaganie: „Wierni Chrystusowi winni mieć szeroki dostęp do Pisma świętego" (KO 22) zaznacza tym samym, że dotychczas dostęp ten był za mało otwarty. Jeśli chodzi o spotkanie i obcowanie $z$ Biblią, katolicy mają wiele do odrobienia. Uświadomiono to sobie - pomijając wcześniejsze dążenia - już na początku naszego stulecia; od tego czasu istnieje także katolicki ruch biblijny, który rozwinął się przede wszystkim po pierwszej wojnie światowej. Mój nauczyciel Pius Parsch powiedział jednak kiedyś: ruch biblijny w kręgach katolickich natrafia na większe trudności niż odnowa liturgiczna. Stale na nowo ulega on zahamowaniu. Kształtowanie liturgii w sposób głęboko przemyślany jest sprawę oczywistą, sprawia ludziom radość i jest stosunkowo łatwe do przeprowadzenia. Jeśli 